\title{
Teacher's Perception on the Effectiveness and Challenges in Using Cooperative Learning in Enhancing Writing Skill
}

\author{
Gomathi Gunasekharan, Hamidah Yamat
}

\begin{abstract}
This research examines the teacher's perception on the effectiveness and challenges in using cooperative learning in enhancing writing skill. There are numerous researches on cooperative learning demonstrating the effectiveness, which has led to the incorporation of social skills into mastering writing skills, namely cooperative writing activities. Vygotsky's sociocultural theory supports the claim that social interactions promote learning. While cooperative learning is regarded highly among pedagogical skills that delivers learning experience, it is always considered ineffective. This research tries to shed some light on what the teachers think about these activities and the challenges that comes with it, whether it is an effective model or not. Three samples were chosen from a primary school to be part of this research. Data collection was done through semi-structured interview, observation checklist and observation notes where the teachers' responses were decoded and analyzed by identifying similar or reoccurring themes. Four themes were identified which were student's involvement, confidence in writing, development in language skills and creativity in writing. The findings showed teachers have a positive perception on the effectiveness of cooperative learning. The challenges on the other hand are time management and class control.
\end{abstract}

Index Terms- Cooperative learning, Primary ESL classroom, Sociocultural theory, Writing skill

\section{INTRODUCTION}

Language is the paramount device of human communication. This urged to embrace a lingua-franca to promote different linguistic context. Consequently, this contemporary era necessitates an international language and English is classified among languages of international communication. Expertise in English ensures the golden opportunity to employ and pursue higher studies. Remarkably, higher studies in many countries require English to access the materials for the enhancement of knowledge. Mackay (2002), affirms "knowledge of English is necessary for accessing many discourses at a global level from international relations to popular culture and academia." Therefore, learners of English language need to excel within

Gomathi Gunasekharan, Universiti Kebangsaan Malaysia, 43600, Bangi,Selangor, Malaysi

Dr Hamidah Yamat, (Associate Professor Dr.) Universiti Kebangsaan Malaysia, 43600, Bangi, Selangor, Malaysia). the confines of accuracy and fluency. In contrast, the English language acquisition turns out to be challenging for second language learners like in Malaysia. "In keeping with the National Education Policy, English is taught as a second language in all-government-assisted schools in the country at both the primary and secondary levels of schooling" (KPM, 1995, p.1) in a sequence of providing essential skills which are listening, speaking, reading and writing. In line with the government's policy on strengthening English, the Blueprint endorses the implementation of the New Standard Curriculum in the primary and secondary schools in 2011 which sees additional time allotted for English subject (Darus and Subramaniam, 2009). Despite acquiring adequate formal English language learning, Malaysian students have been incapable of achieving the appropriate competency. In a report that was released in 2013, it was found out that students who had completed primary education and was proficient in English was less than 50\% (KPM 2013).

Employment of traditional method such as audio lingual and grammar translation method have not improved the learner's writing skill. In accordance with that, ESL learners require additional practice to refine their writing and an alternative strategy needs to be implemented for the learners who have difficulties in writing. Therefore, teachers need to combat the issue by inculcating new and innovative strategies that could be applicable in the student's writing lesson.

In conjunction with that, cooperative learning in the classroom has brought ample of prerequisites. This learning method is emphasized in the Constructivist theory where meaningful context is created through the use of authentic task. Mulligan \& Garofalo (2011) found out that students' interaction in the classroom is enhanced through cooperative learning, which in turn develops learners' linguistic, social and communicative skill. This method provides a remarkably high chance forinteraction between students with consequential input and output in an encouraging atmosphere (Ahangari\&Samadian, 2014). Vygotsky (1978) proclaimed 'teachers use collaborative learning where less competent learners develop with the help of more skillful peers'. For instance, intermediate learners can share their ideas while advance learners facilitate in the syntactic rules of language in writing. Elola and Oskoz (2010) found that cooperative learning helps students build on their content for writing. 
During the brainstorming session, a sentence will be shared by a learner and will be discussed by other group members before adding into the essay. Thus, cooperative writing diminishes learners' anxiety of writing alone and stimulates active participants who would intensify their writing gradually.

This study was designed primarily to determine the teacher's perception on the effectiveness of cooperative learning in enhancing writing skill.

Particularly, this research study attempted to answer the following questions.

1) How the teachers perceive the effectiveness of using cooperative learning to enhance writing skill?

2) How the teachers perceive the challenges of using cooperative learning to enhance writing skill?

\section{METHODOLOGY}

\section{A. Research Design}

The purpose of this study is to explore the perception of teachers on the effectiveness of using cooperative learning in enhancing writing skill as well as the possible challenges faced by them. For this research, a qualitative case study using interviews, observational checklist and observational notes was chosen as it will allow the researcher in exploring the teacher's perception on cooperative learning strategies. This study also enables the researchers to investigate teacher's perception on the challenges of using cooperative learning strategies in reinforcing the students' writing skill. Hence, this study solely focused on teacher's point of view regarding the usage and effectiveness of cooperative writing have on their English language learners.

\section{B. Population}

The sampling used in qualitative research was a non-probability sampling. Marshall (1996), stated that in a qualitative research, a researcher will be able to recruit only specific and relatable population to investigate specific topic when using non-probability sampling strategy.Three participants were selected as sample. Purposive sampling was used to focus on particular characteristics of a population that are of interest, which in this research are teachers from a local primary school who utilizes cooperative learning strategies in their teaching and learning of English lesson. The sample being studied is not representative of the whole Malaysian English teachers. Purposive sampling was used as the strength of the method lies in its intentional bias (Bernard 2002; Lewis and Sheppard, 2006). It is seen as a choice as the sample units possess characteristics that are of particular interest. Observation was carried out to ensure the data collected would be relevant and robust in better understanding the perception of the participants on cooperative learning strategies.

\section{Research Instrument}

Semi-structured interview is one of the best ways in collecting data through interview as it provides a set of questions with open ended answers that can be used fordiscussions. The questions are set in a way that ensures the researcher will be able to cover all the research questions and objectives. Semi-structured interviews steer the interview in meeting the objectives of the research yet allow for flexibility. It will allow participants to discuss and raise issues that may not have been considered. A semi structured interview was instrumented on three purposively selected participants. The interview questions were content validated by two experienced ESL teachers to ensure that the questions measure this study's objectives. Before starting the interview, the participants were briefed on its purpose. Member checking (Creswell, 2014) was also carried out at the end of the interview by asking teachers to verify or disconfirm the researcher's interpretations of their perceptions.

Observation methods are mostly unstructured in a qualitative research. Sometimes, however, qualitative observation may also be structured, given the parameters. With unstructured observation, the researcher enters the 'field' with no predetermined schedule as to what they may or may not see or hear. In order to use this approach effectively, an observation protocol was required to record all the observations done by the researcher. Researcher used observation checklist as well as observation notes to record all the observation data. This helped the researcher on keeping tabs with participants responses.

\section{Data Collection Method}

Researcher gained approval from the District Education Office (PPD), the chosen school site where the study took place as well as the teachers involved to gain their approval and getting them informed regarding the study. The informed consent forms were distributed to the participants which was then signed and collected within two weeks of the beginning of study (Yin, 2014). The observations were conducted throughout the eight-week study. Observation was done once during the beginning (week 1) and once again during the ending (week 8) of the study. During observation, researcher took specific notes such as seating arrangements and overall class setting. This enabled the researcher to obtain unfiltered and unbiased reflections from the participants. After each cooperative lesson, data regarding the lesson was collected through semi-structured interview. The interview was recorded through a smartphone.

\section{E. Data Analysis Method}

According to Boyatzis (1998), thematic analysis is suitable to be used because it allows researchers to manage data into interpretable themes. In this analysis, data was coded into themes which involves three steps according to thematic analysis procedure which is to identify responses as codes, create constituent themes based on the codes, and refine constituent themes into major themes. The data was qualitatively analyzed by finding similar themes to be coded. It was cross-case analyzed among the participants to get focused data on their perception. The participants' responses were recorded and transcribed. Data was organized into similar reoccurring themes for easy verification, revision, and the drawing of conclusions (Miles \& Huberman, 1994). After that, the coding was narrowed down to identify the ordinary theme which is the perception of the teachers on the effectiveness of using cooperative learning to enhance 
writing skill. Data from observation was used to triangulate the data, thus giving out a robust and reliable outcome.

\section{RESULTS AND DISCUSSIONS}

This section presents the findings with regards to the first research question.

\section{Student's involvement}

\begin{tabular}{|c|c|c|c|}
\hline \multicolumn{3}{|c|}{ Evidence } & \multirow{2}{*}{ Themes } \\
\hline $\begin{array}{l}\text { Observation } \\
\text { Checklist }\end{array}$ & Interview & $\begin{array}{l}\text { Observation } \\
\text { Notes }\end{array}$ & \\
\hline $\begin{array}{l}\text {-Collaboratively } \\
\text { producing a } \\
\text { product. } \\
\text {-Participating in } \\
\text { discussions } \\
\text {-Presenting }\end{array}$ & $\begin{array}{l}\text { "The students were very active and } \\
\text { seemed very engaged while doing the } \\
\text { group works. They get very excited } \\
\text { when I teach writing lesson through the } \\
\text { use of cooperative activities". (Q3, T1) } \\
\text { "The students loved doing cooperative } \\
\text { activities with their friends. They } \\
\text { showed more enthusiasm in doing } \\
\text { writing lessons in groups compared to } \\
\text { doing it as individual tasks". (Q3, T2) } \\
\text { "Students that were non-participant } \\
\text { during individual tasks showed active } \\
\text { involvement when it comes to group } \\
\text { works". (Q6, T3) } \\
\text { "The students always show higher level } \\
\text { of engagement and good cooperative } \\
\text { skills when it comes to doing group } \\
\text { works". (Q6, T1) }\end{array}$ & $\begin{array}{l}\text { The students were } \\
\text { singing and having } \\
\text { a good time doing } \\
\text { group works. } \\
\text { Celebrating with } \\
\text { their friends. }\end{array}$ & Students' Involvement \\
\hline
\end{tabular}

According to the respondents, students were excited to participate in group activities. This is evident from the answers from the respondents for the interview questions. Words such as engaging and fun were frequently used by the respondents to answer these questions. The researcher through observation noticed that the students did show a higher level of engagement and had fun through learning writing as a group. This supports the answers from the respondents even further.

The answers from the respondents are further supported by the findings from observation where students were seen actively participating in discussions and producing a work. Students also encouraged one another and celebrating their team success as their own. It is also stated in the researcher's observation notes that the students were singing and having a good time doing group works. This further supports the respondents' answer about students showing higher engagement and having fun during group works. 


\section{Confidence in writing}

\begin{tabular}{|c|c|c|c|}
\hline \multicolumn{3}{|c|}{ Evidence } & \multirow{2}{*}{ Themes } \\
\hline $\begin{array}{l}\text { Observation } \\
\text { Checklist }\end{array}$ & Interview & $\begin{array}{l}\text { Observation } \\
\text { Notes }\end{array}$ & \\
\hline $\begin{array}{l}\text {-Independently } \\
\text { producing a } \\
\text { product } \\
\text {-Students are } \\
\text { comfortable } \\
\text { sharing ideas, } \\
\text { questions, } \\
\text { concerns or needs. }\end{array}$ & $\begin{array}{l}\text { "In my opinion, students have a positive outlook } \\
\text { about group works as they are interacting with } \\
\text { their friends which in turn creates a very } \\
\text { comfortable environment for them to work in." } \\
(\mathrm{Q} 4, \mathrm{~T} 2) \\
\text { "Students are brave in expressing their thoughts } \\
\text { and ideas as they feel comfortable to be working } \\
\text { with their peers". (Q4, T3) } \\
\text { "When there is a spelling mistake, other students } \\
\text { from the same group will help in rectifying it. } \\
\text { This in turn raises students' confidence level as } \\
\text { they feel what they have written is correct". (Q10, } \\
\text { T1) } \\
\text { "Students are brave and certain in writing as they } \\
\text { get appropriate amount of peer feedback". (Q10, } \\
\text { T2) }\end{array}$ & $\begin{array}{l}\text {-Encourage one } \\
\text { another in } \\
\text { completing a } \\
\text { writing task. } \\
\text {-Students } \\
\text { seemed to be } \\
\text { much more } \\
\text { confident with } \\
\text { constant help } \\
\text { and motivation } \\
\text { from friends. }\end{array}$ & $\begin{array}{l}\text { Confidence in } \\
\text { writing }\end{array}$ \\
\hline
\end{tabular}

Based on the respondent's answers during the interview, all of them agreed that cooperative learning increases confidence level in students' writing skill. Respondents used words such as comfortable, certain and brave when answering these questions. Through observation, researcher noticed that students encourage one another in completing a writing task. Students seem to be much more confident in completing the work with constant help and motivation from their friends. Students are also very brave in presenting their work in front of the class. It can be said that through cooperative learning and proper peer feedback, students are much more confident in expressing their ideas and coming up with a quality end product. The respondents' statements were strongly supported with the data collected through observation. 


\section{Development in language skills}

\begin{tabular}{|c|c|c|c|}
\hline \multicolumn{3}{|c|}{ Evidence } & \multirow{2}{*}{ Themes } \\
\hline $\begin{array}{l}\text { Observation } \\
\text { Checklist }\end{array}$ & Interview & $\begin{array}{l}\text { Observation } \\
\text { Notes }\end{array}$ & \\
\hline $\begin{array}{l}\text {-Writing activities. } \\
\text {-Evidence of } \\
\text { developing writing } \\
\text { skills. } \\
\text {-Independent } \\
\text { practice/application. }\end{array}$ & $\begin{array}{l}\text { "Comparing the students' performance in } \\
\text { writing before and after cooperative learning } \\
\text { strategy being implemented, I have to say that } \\
\text { students showed massive improvement in the } \\
\text { language proficiency. They were able to } \\
\text { construct sentences with minimal amount of } \\
\text { spelling errors". (Q5, T1) } \\
\text { "Students showed improvement in the use of } \\
\text { vocabulary when they work in groups. } \\
\text { Students learn new words from each other, } \\
\text { thus expanding their range of vocabulary". } \\
\text { (Q5, T2) } \\
\text { "I definitely notice an increase in the students' } \\
\text { writing performance when they work in group. } \\
\text { They can come up with a writing product that } \\
\text { has good sentence structures when working in } \\
\text { groups as opposed to writing individually". } \\
\text { (Q5, T3) }\end{array}$ & $\begin{array}{l}\text {-Creating } \\
\text { sentence with } \\
\text { few to no } \\
\text { spelling errors. } \\
\text {-Good usage of } \\
\text { vocabulary. } \\
\text {-Appropriate } \\
\text { sentence } \\
\text { structure. }\end{array}$ & $\begin{array}{l}\text { Development in } \\
\text { language skills }\end{array}$ \\
\hline
\end{tabular}

The respondents unanimously agreed that students showed an increase in their development of language skills. According to them, language skills such as spelling, usage of grammar items, sentence structure as well as vocabulary showed significant improvement. Students were able to come up with a grammatically correct sentence with few to no spelling errors. The data from the teachers' interview responses showed that students have made an improvement in the vocabulary used in essay writing. Students learned new vocabulary as they interacted with each other during lessons.

During observation, researcher noticed that students have developed good language skills when going through their written works. It had very minimal spelling errors, a good usage of vocabulary and appropriate sentence structure. This was also evident when the students were presenting their works in front of the class. All these extra data further strengthen the respondents view that the students have indeed developed a good set of language skills. 


\section{Creativity in writing}

\begin{tabular}{|c|c|c|c|}
\hline \multicolumn{3}{|c|}{ Evidence } & \multirow{2}{*}{ Themes } \\
\hline $\begin{array}{l}\text { Observation } \\
\text { Checklist }\end{array}$ & Interview & $\begin{array}{l}\text { Observation } \\
\text { Notes }\end{array}$ & \\
\hline $\begin{array}{l}\text {-Collaboratively } \\
\text { problem solving. } \\
\text {-Independently } \\
\text { solving a problem. } \\
\text { (Bloom's } \\
\text { Taxonomy) }\end{array}$ & $\begin{array}{l}\text { "When students sit in a group, they share } \\
\text { their ideas from multiple perspective which } \\
\text { helps the students to come up with a very } \\
\text { creative write up". (Q7, T1) } \\
\text { "Students" writing becomes much more } \\
\text { creative as they share many ideas when } \\
\text { discussing in groups. The different } \\
\text { perspectives change the way the students } \\
\text { look at a topic". (Q7, T3) } \\
\text { "One of the advantages of cooperative } \\
\text { learning is that it induces creativity among } \\
\text { students. They become more creative in } \\
\text { their writing". (Q7, T2) }\end{array}$ & $\begin{array}{l}\text {-Students share } \\
\text { idea and } \\
\text { perspective to } \\
\text { come up with a } \\
\text { creative write up. } \\
\text {-Share ideas to } \\
\text { complete work. }\end{array}$ & $\begin{array}{l}\text { Creativity in } \\
\text { writing }\end{array}$ \\
\hline
\end{tabular}

The respondents also expressed that students were more creative in their writing when they are sat in a collaborative environment. This change was due to the presence of multiple perspective on one topic or issue. Students in one group may have different ideas and opinions regarding one topic and this helps promote creativity among students. Through observation, researcher noticed the way in which students tackle a given topic. They share their ideas and perspectives which then helps them to come up with a very creative and interesting write up. They are not stuck with one idea and this helps in completing their work smoothly. In observation notes, it was stated that students shared ideas among themselves in order to complete their work. All the data points that cooperative learning promotes creative writing among students. 
This section presents the findings with regards to the second research question.

\section{Time management}

\begin{tabular}{|c|c|c|c|}
\hline \multicolumn{3}{|c|}{ Evidence } & \multirow{2}{*}{ Themes } \\
\hline $\begin{array}{l}\text { Observation } \\
\text { Checklist }\end{array}$ & Interview & Observation Notes & \\
\hline $\begin{array}{l}\text {-Not enough } \\
\text { time to complete } \\
\text { an activity. }\end{array}$ & $\begin{array}{l}\text { "Time constraint is something that I have to } \\
\text { face especially when there are lessons and } \\
\text { syllabus that needs to be finished at the end } \\
\text { of the schooling period". (Q8, T1) } \\
\text { "Even though cooperative learning is an } \\
\text { effective way of teaching writing skill, it } \\
\text { consumes a lot of time especially during } \\
\text { planning and delivery stages". (Q8, T2) }\end{array}$ & $\begin{array}{l}\text {-Teachers take a lot of } \\
\text { time to deliver the } \\
\text { lesson. } \\
\text {-Students do not have } \\
\text { enough time to } \\
\text { complete an activity. }\end{array}$ & Time management \\
\hline
\end{tabular}

Participants find it difficult to plan and deliver a cooperative learning lesson as they feel it is time consuming. They feel they don't have enough time to deliver a proper lesson. Cooperative learning strategy needs more time compared to conventional learning strategy. The amount of time they need to prepare and undertake this learning strategy is much higher than the normal learning strategy that they use. This in turn makes it harder for them to complete their lesson within the given time. 


\section{Class control}

\begin{tabular}{|c|c|c|c|}
\hline \multicolumn{3}{|c|}{ Evidence } & \multirow{2}{*}{ Themes } \\
\hline $\begin{array}{l}\text { Observation } \\
\text { Checklist }\end{array}$ & Interview & Observation Notes & \\
\hline $\begin{array}{l}\text {-Could not provide } \\
\text { equal attention to all } \\
\text { students. }\end{array}$ & $\begin{array}{l}\text { "It is difficult to deliver } \\
\text { knowledge constantly to every } \\
\text { student as my class consists of } \\
\text { students with varying degrees } \\
\text { of proficiency. This makes it } \\
\text { hard for all students to } \\
\text { contribute to a group work". } \\
\text { (Q8, T2) } \\
\text { "Cooperative learning needs } \\
\text { more attention from us as we } \\
\text { have to constantly move around } \\
\text { the class to keep all the students } \\
\text { in check". (Q8, T1) }\end{array}$ & $\begin{array}{l}\text {-Teachers struggle to } \\
\text { deliver same amount of } \\
\text { knowledge to all the } \\
\text { students. } \\
\text {-Slow learners need more } \\
\text { attention. }\end{array}$ & Class control \\
\hline
\end{tabular}

Respondents noted the difficulty in controlling their class when applying cooperative learning strategy. As the class consists of students with varying level of proficiency, it is always difficult to deliver the same amount of knowledge consistently throughout the class. It is also difficult to control a group of students as compared to dealing with them individually. Teachers need to constantly stay on their feet and be extra creative when handling a group of students who are involved in cooperative learning strategy.

\section{CONCLUSION}

In essence, this study showed that teachers have a positive perception on the effectiveness of cooperative learning in enhancing students' writing skill. By collecting and triangulating data from semi structured interviews, observation checklist and observation note, it can be concluded that cooperative learning does enhance writing skills of the students. Students seemed to be much more involved in the lesson and they are confident in carrying out activities given by the teachers. There is also a substantial increase in their language skill as well as their level of creativity. Teachers face a few challenges in their attempt to conduct cooperative learning lessons such as time management and class control. Even though faced with these challenges, teachers' perception remained unchanged as they feel the positives of cooperative learning strategy outweighs the negatives, thus enhancing writing skill.

\section{RECOMMENDATIONS}

The findings serve as impetus for other researchers to further understand the perception of teachers on the effectiveness of cooperative learning in enhancing students' writing skill.
As this is a small-scale study, the findings cannot be generalized, rather can only be used to predict an outcome of

a study with similar scenario. In order to improve this, a multiple case study can be carried out to compare the outcomes of the findings. Future researchers can choose homogeneous or heterogeneous population in order to collect data from a wide source.

This study could also be developed for other parts of language skills such as speaking, listening and reading. In this study, the main focus was on the perception of teachers on the effectiveness of cooperative learning in enhancing writing skills. Future studies can look into the perception of teachers on the effectiveness of cooperative learning in enhancing skills such as listening, speaking or reading or all the four skills combined for a more comprehensive finding.

\section{REFERENCES}

[1] Ahangari, S., \&Samadian, Z. (2014). The Effect of Cooperative Learning Activities on Writing Skills of Iranian EFL Learners. Linguistics and Literature Studies, 2(4), 121-130

[2] Bernard, H.R. 2002. Research Methods in Anthropology: Qualitative and quantitative methods. 3rd edition. AltaMira Press, Walnut Creek, California

[3] Boyatzis, Richard. (1998). Transforming Qualitative Information: Thematic Analysis and Code Development

[4] Creswell, J. W. (2014). Research Design: Qualitative, Quantitative and Mixed Methods Approaches (4th ed.). London: Sage Publications Ltd.Gibson, S.A

[5] Darus, S. \& K. Subramaniam (2009). Error Analysis Of The Written English Essays Of Secondary School Students In Malaysia: A Case Study. European Journal Of Social Sciences, 8(3), 483-495

[6] Elola, I., \&Oskoz, A. (In Press). A Social Constructivist Approach To Foreign Language Writing In Online Environments. In G. Levine \& A. Phipps (Eds.), Critical and Intercultural Theory and Language Pedagogy (Pp.185-201). Boston: Cengage Heinle

[7] Kementerian Pendidikan Malaysia (1995) Sukatan Pelajaran SekolahRendah Bahasa Inggeris. Kuala Lumpur: Dewan Bahasa dan Pustaka. 
[8] Kementerian Pendidikan Malaysia (2013) Malaysian Education Bluprint 2013-2025. Kuala Lumpur: Dewan Bahasa dan Pustaka.

[9] Lewis, J.L., \& Sheppard, S.R.J. (2006). Culture and communication. Landscape and Urban Planning 77: pp. 291-313

[10] Marshall, M. N. (1996). Sampling for qualitative research. Family practice, 13(6), 522-526

[11] McKay, S. L. (2002). Teaching English as an International Language. Oxford: Oxford University Press.

[12] Miles, MB. \& Huberman, AM. (1994). Qualitative Data Analysis (2nd edition). Thousand Oaks, CA: Sage Publications

[13] Mulligan, C., \& Garofalo, R. (2011). A Collaborative Writing Approach: Methodology and Student Assessment

[14] Vygotsky LS (1978) Mind in Society: The Development Of Higher Psychological Processes. Harvard University Press, Cambridge.

[15] Yin, R. (2014). Case study research: Design and methods (5th ed.). Thousand Oaks, CA: Sage Publications.

Gomathi Gunasekharanis a student who is pursuing her Masters of Education in TESL in UniversitiKebangsaanMalaysia, 43600 Bangi, Selangor, Malaysia. She graduated from Teachers' Training Institute of TengkuAmpuanAfzan Campus in 2017 with a Bachelor's Degree in Teaching. She is teaching atSekolahKebangsaanKangkar Pulai 2, Skudai, Johor, Malaysia since 2018. She has participated in International Invention \& Innovative Competition (InIIC Series 2/2019) under Higher Institution Students (Social Science) category.

Dr HamidahYamatis an Associate Professor at Faculty of Education in University Kebangsaan Malaysia, 43600 Bangi, Selangor, Malaysia. She obtained her M.A Universiti Putra Malaysia and her Ph.D. from University of Exeter, UK. Her research interest is second language acquisition and case study. She has presented papers at national and international levels. Besides that, she also has published several papers in areas related to second language acquisition. 